recently the work of Legg, Curnow \& Simpson (1950) has focused attention on the oestrogens in grass which they show tend to be higher in spring grass.

Then again there is the marked laxative effect of young grass, particularly for cattle that have just been turned out, a factor which markedly affects its value at that time. Finally, we have troubles such as blowing or bloat in cattle on grass at certain periods of the year when the animals are unable to eliminate the rapidly formed gas from the rumen, and the work of Ferguson ( $194^{8}$ ) has shown the presence of a compound which affects muscle activity and is present in legumes at certain seasons.

A good deal more information is still needed before a final assessment can be made of the feeding value of grassland, and the animal itself is the only final and accurate yardstick. It is, however, possible to forecast the value for most purposes more accurately to-day than before.

\title{
REFERENCES
}

Elliot, W. E., Orr, J. B. \& Wood, T. B. (r925). Scot. J. Agric. 8, 349.

Fagan, T. W. (1929). Welsh f. Agric. 5, 99.

Fagan, T. W. \& Jones, T. H. (1924). Bull. Welsh Pl. Breed. Sta., Ser. H, no. 3.

Fagaun, T. W. \& Milton, W. E. J. (1931). Welsh F. Agric. 7, 246.

Fergson, W. S. (1948). Nature, Lond., 161, 816.

Legg, S. P., Curnow, D. H. \& Simpson, S. A. (1950). Biochem. F. 46, xix.

Lewis, A. H. (1939-40). F. Minist. Agric. 46, 77.

Morris, S., Wright, N. C. \& Fowler, A. B. (1936). 7. Dairy Res. 7, 97.

Shutt, F. T., Hamilton, S. N. \& Selwyn, H. H. (1928). F. agric. Sci. 18, 41 I.

Shutt, F. T., Hamilton, S. N. \& Selwyn, H. H. (1930). F. agric. Sci. 20, 126.

Shutt, F. T., Hamilton, S. N. \& Selwyn, H. H. (1932). F. agric. Sci. 22, 647.

Waite, R. \& Sastry, K. N. S. (1949). Emp. F. exp. Agric. I7, I79.

Watson, S. J. (1949). Feeding of Livestock. Edinburgh: Nelson.

Watson, S. J. (195 I). Grassland and Grassland Products. London: Arnold.

Wilson, D. Jr. (1886). Trans. Highl. agric. Soc. Scot. (Ser. 4), I8, I48.

Wilson, D. Jr. (1889). Trans. Highl. agric. Soc. Scot. (Ser. 5), I, 1.

Woodman, H. E., Blunt, D. L. \& Stewart, J. (1926). F. agric. Sci. 16, 205.

Woodman, H. E., Blunt, D. L. \& Stewart, J. (1927). F. agric. Sci. x7, 209.

Woodman, H. E. \& Norman, D. B. (1932). F. agric. Sci. 22, 852.

Woodman, H. E., Norman, D. B. \& Bee, J. W. (I928). F. agric. Sci. I8, 266.

Woodman, H. E., Norman, D. B. \& Bee, J. W. (1929). F. agric. Sci. 19, 236.

Woodman, H. E., Norman, D. B. \& French, M. H. (1931). F. agric. Sci. 21, 267.

Woodman, H. E. \& Underwood, E. J. (1932). F. agric. Sci. 22, 26.

\section{The Utilization of Herbage Protein by Animals}

\section{By R. L. M. Synge, Rowett Research Institute, Bucksburn, Aberdeenshire}

Between 80 and $90 \%$ of the nitrogen of herbage is, beyond question, protein. The remainder, the so-called 'non-protein nitrogen', consists mostly of free amino-acids, but also includes nucleic acids, purine and pyrimidine bases, choline and betaines, alkaloids, peptides, ammonia, urea, nitrate and other compounds. Chibnall (1939) and Lugg (1949) have well summarized much of the chemical information available. Most of the protein seems to be in the chloroplasts; the substances of low molecular weight behave as if in solution in the tissue juices.

The usefulness of protein to such animals as the rat, the chicken, the pig and man is understood nowadays to depend chiefly on amino-acid composition and particularly on the content of about ten so-called 'essential' amino-acids. These are not well 
represented among the free amino-acids of the tissues of the green plant, where the 'non-essential' glutamic and aspartic acids and their amides, glutamine and asparagine, with alanine, serine and $\gamma$-aminobutyric acid tend to predominate, much as in the blood and tissue juices of animals. However, the proportions of amino-acids in the true protein of the leaf are much more favourable to the requirements of these animals, vary very little with season or species, and put the leaf proteins into the category 'first class' (although there is a tendency for methionine to be low, as in so many other proteins). Thus for these animals leaf protein is more valuable than most other types of plant protein. Given suitable maceration to render it accessible, leaf protein is well hydrolysed by the intestinal proteases. Its drawback as a main source of protein is the large quantity of indigestible material, mainly carbohydrates, that accompanies it, and this is the main factor limiting its consumption by these animals.

Some animals, however, live mostly on leaves. They include such domestic animals as the horse, the rabbit, the goose and, most important, the ruminating cow, sheep and goat. In all of them the intestines are specially adapted to give space and time for extensive microbial fermentation of the leaf carbohydrates. In the non-ruminants mentioned this adaptation is in the caecum and colon, the stomach and small intestine being little modified. In the ruminants there is great modification of the intestinal tract above the stomach, the food undergoing microbial fermentation in the rumen immediately on ingestion. Too little is known of the digestive physiology of the nonruminant herbivores, and I will therefore only make two points about them. First that digestion and absorption of leaf protein may be fairly complete in the upper alimentary tract, and their protein economy therefore much the same as that of nonherbivores. Presumably the protein of the micro-organisms of their large intestines is mostly lost. The source of nitrogen for growth of these organisms may well be excess nitrogen from the animal's metabolic pool that would otherwise be excreted, entering the gut as compounds of low molecular weight from the blood; it would thus represent little serious nitrogen loss to the animal; the coprophagy of the rabbit probably turns this loss to gain. My second point is that the digestive physiology of these animals ought to be studied in parallel with that of the ruminant since, regardless of direct economic motives, such knowledge may well hasten our understanding of ruminant digestion and perhaps of other means of making use of herbages. The economic stakes are to be calculated in millions of pounds.

Although the protein metabolism of ruminants has been a controversial subject for half a century, it is possible to give a non-controversial statement in qualitative and general terms of what happens to nitrogen compounds in the rumen.

Protein of the food is in part broken down by micro-organisms and in part passes on unchanged to the abomasum (or true stomach); part of what is broken down by the micro-organisms is assimilated by them and built into microbial protein which likewise passes on to the abomasum. Another part is converted to ammonia and is absorbed by the animal directly from the rumen. Urea and other nitrogenous compounds of low molecular weight in the food, in the saliva or entering the rumen from the animal's blood may undergo the same treatments by the micro-organisms. It is also very generally assumed that at least a fair proportion of the protein digested by 
the animal in the abomasum and small intestine is microbial protein, and it has been shown experimentally that the protein of mixed rumen micro-organisms is a highgrade, well-balanced protein for rats (McNaught, Smith, Henry \& Kon, 1950). The fact that ruminants show none of the signs of amino-acid imbalance on being fed exclusively on proteins that are ill-balanced for rats, chickens and men is therefore taken to be explained by the contribution of microbial protein, and the requirements for absorbed amino-acids are assumed to be not dissimilar to those of the animals whose requirements have been studied in detail.

Beyond this point nearly everything is controversial. Because the mixture of amino-acids absorbed by the ruminant is a well-balanced one, it does not follow that the overall utilization of protein is always efficient. Two opposing tendencies can be seen at work: (a) non-protein nitrogen, poor in 'essential' amino-acids, entering the rumen is ennobled to microbial protein; $(b)$ food protein of good amino-acid composition is attacked in the rumen and converted into ammonia which is to a great extent absorbed (McDonald, $1948 a$ ) and excreted as urea.

The important thing is to ascertain, in particular instances, whether processes of type $(a)$ or of type $(b)$ predominate. This has very rarely been done unequivocally, and it is worth pointing out here that the conventional 'digestibility' studies, traditional to agricultural chemistry, are ill-adapted for the purpose; to know the net absorption of nitrogen from the intestine provides no evidence whether it has entered the animal as ammonia or as essential amino-acids. At this stage of development of the subject practical experiments on growth, milk yield and so forth or else thoroughgoing nitrogen-balance experiments, in which urinary nitrogen is measured, seem preferable to 'digestibility' experiments.

It seems conclusively established that supplementation of certain diets with urea can lead to good use being made of this supplementary nitrogen. This is known to depend very much on the type and amount of carbohydrate simultaneously fed. The best results have been with beef cattle, and fewer favourable experiences with dairy cattle (which require a higher protein concentration in the diet) have been recorded. It is perhaps significant that these favourable experiences have mainly been in the U.S.A., where maize plays a much larger part in cattle feeding than it does in northern Europe. McDonald (1948b, $c, 1952)$ has studied the rates at which different proteins were converted to ammonia in the rumen of the sheep, and found zein, the chief protein of maize, to be converted very slowly indeed. He was able, by making use of its unusual solubility in aqueous alcohol and of its low lysine content, to study quantitatively the disappearance of zein and the simultaneous formation of lysine-rich microbial protein in the rumen. It would help if similar specific tests were available for studying the fate of other proteins. Experiments here have confirmed that casein is very rapidly deaminated in the rumen, and is consequently of little value as a protein supplement when administered to sheep unless the rumen is by-passed and the casein is given directly into the duodenum (Cuthbertson \& Chalmers, 1950). It has also been possible to correlate the greater value of herring-meal supplements over casein supplements for sheep with the lower evolution of ammonia that is observed from the herring meal (Chalmers \& Synge, 1950, and unpublished work). 
From all this it is evident that quite other factors than amino-acid composition determine the value of protein or non-protein nitrogen to a ruminant animal: the amount and nature of the carbohydrate that is being simultaneously fermented, the solubility of the protein and its susceptibility to the microbial proteases are obviously among the important factors.

An examination of the utilization of herbage protein from this angle reveals a host of problems, as well as the futility of attacking them without paying simultaneous attention to the fate of the carbohydrates. I cannot do more than name a few of the problems that seem relevant at the present time. Heavy nitrogenous manuring of pastures is essential for high yields, and this at the same time raises the protein content of the grass and lowers the content of soluble carbohydrate. The soluble-carbohydrate content also fluctuates greatly with season, and it seems possible that these changes, rather than changes in protein content, may be responsible for some of the differences that are said to exist between the value of spring and autumn grass. Again, it is quite possible that in modern highly fertilized pastures protein content has been pushed altogether too high for efficient utilization, and that dairy cattle should have some supplementary feeding with carbohydrate all the year round. The special hazard of high nitrate content in the herbage should be noted in view of the danger of nitrite formation in the rumen (Lewis, I95I). Finally, I think a big mistake has been made in assessing conservation methods solely on the conservation of 'digestible crude protein' without reference to practical results. This sort of approach has done much to lower the reputation of science in the eyes of the practical man. The question of hay versus silage is not settled by quoting figures for digestible crude protein. The making of silage results in conversion of much of the protein of grass into soluble nitrogenous compounds of lower molecular weight and in fermenting away much of the soluble carbohydrate present. The consumption of silage may thus lead to a predominance of deaminative reactions over protein synthesis in the rumen. With hay, this predominance cannot be so great. So far there has been too much propaganda and too little experiment in matters of grass conservation.

There are no reasonable evolutionary grounds for regarding the ruminant as well adapted for digesting and assimilating protein under modern dairy conditions. The primary adaptation of the ruminant is clearly towards the use of carbohydrates not available to other animals. Under wild conditions at some seasons (coinciding with parturition and lactation, when the physiological demand for protein is greatest) abundant protein is available in the herbage and the animal can afford even to waste it. At other times, when the animal has to live on a few old sticks and straws, a very efficient mechanism for recovering protein from the waste nitrogen compounds of its own body fluids comes into play, and this has probably been the aspect of protein digestion in the ruminant that has undergone the greatest evolutionary adaptation.

If I have succeeded in showing how complicated the problems are and what a little way we have advanced towards understanding them, I shall be quite satisfied. It will require a much greater knowledge of the rumen micro-organisms, of the chemistry of herbage and of the biochemistry and physiology of the fermentations and absorptions 
that are proceeding before genuinely scientific recommendations can be made. It is sheer presumption to recommend changes in farm practice on the basis of a few Kjeldahl figures.

\section{REFERENCES}

Chalmers, M. I. \& Synge, R. L. M. (1950). Brit. F. Nutrit. 4, ix.

Chibnall, A. C. (1939). Protein Metabolism in the Plant. New Haven: Yale University Press.

Cuthbertson, D. P. \& Chalmers, M. I. (I950). Biochem. F. 46, xvii.

Lewis, D. (1951). Biochem. 7. 48, 175.

Lugg, J. W. H. (1949). Adv. Prot. Chem. 5, 229.

McDonald, I. W. (1948a). Biochem. F. 42, 584 .

McDonald, I. W. (I948b). Studies in the metabolism of sheep with special reference to the digestion of protein. Dissertation, University of Cambridge.

McDonald, I. W. (r948c). F. Physiol. ro7, 2 r $P$.

McDonald, I. W. (I 952). Biochem. F. 5r, 86.

McNaught, M. L., Smith, J. A. B., Henry, K. M. \& Kon, S. K. (1950). Biochem. F. 46, 32.

\section{The Carbohydrate Constituents of Herbage}

\section{By E. G. V. Percival*, Department of Chemistry, King's Buildings, University of Edinburgh}

Although an immense amount of routine analytical work has been carried out on forage crops in the past, we are still ignorant, in the main, of what is measured under such headings as crude fibre, total carbohydrate and so on. With the advent of new techniques such as chromatography and desalting by ion-exchange and electrophoretic methods, work is now in progress to fill in these gaps in our knowledge. It is still too early to do more than indicate the probable nature of the carbohydrate components, much less to evaluate them quantitatively, and it may be many years before a complete picture can be drawn. It is perhaps appropriate at this point to emphasize the need for the examination of pure species grown and harvested under controlled conditions so that the seasonal variations of the constituents, for example the fructosans, may be followed.

For convenience we may divide the carbohydrates of herbage into those that play a part in the structure of the plant, and the non-structural components such as the free sugars and oligosaccharides and the reserve polysaccharides.

\section{Cellulose}

\section{Structural polysaccharides}

The most important structural component from the quantitative standpoint is, of course, cellulose, and although no studies of the fine structure of cellulose specimens obtained from herbage appear to have been carried out, it is reasonable to suppose that there is no essential difference between cotton (or wood) cellulose and the cellulose of herbage. Indirect evidence in favour of this assumption is afforded by the fact that celluloses isolated from such dissimilar sources as the cell-wall of the pear (Hirst, Isherwood, Jermyn \& Jones, 1949) and of marine algae (Percival \& Ross, 1949) are fundamentally the same as cotton cellulose, being composed of long chains of I : 4-linked $\beta$-D-glucopyranose residues. One would hesitate to affirm, however, 